\title{
The Effect of Synthetic Hydrated Calcium Aluminate Additive on the Hydration Properties of OPC
}

\author{
Jolanta Doneliene, Anatolijus Eisinas, Kestutis Baltakys, and Agne Bankauskaite \\ Department of Silicate Technology, Kaunas University of Technology, Radvilenu 19, LT-50270 Kaunas, Lithuania \\ Correspondence should be addressed to Anatolijus Eisinas; anatolijus.eisinas@ktu.lt
}

Received 12 May 2016; Revised 22 June 2016; Accepted 17 July 2016

Academic Editor: Cristina Leonelli

Copyright ( 2016 Jolanta Doneliene et al. This is an open access article distributed under the Creative Commons Attribution License, which permits unrestricted use, distribution, and reproduction in any medium, provided the original work is properly cited.

\begin{abstract}
The effect of synthetic $\mathrm{CAH}\left(130^{\circ} \mathrm{C} ; 8 \mathrm{~h} ; \mathrm{CaO} /\left(\mathrm{SiO}_{2}+\mathrm{Al}_{2} \mathrm{O}_{3}\right)=0.55 ; \mathrm{Al}_{2} \mathrm{O}_{3} /\left(\mathrm{SiO}_{2}+\mathrm{Al}_{2} \mathrm{O}_{3}\right)=0.1,0.15\right)$ with different crystallinity on the hydration kinetics of OPC at early stages of hydration was investigated. Also, the formation mechanism of compounds during OPC hydration was highlighted. It was determined that the synthetic $\mathrm{CAH}$ accelerated the initial reaction and shortened the induction period. Also, the second and third exothermic reactions begun earlier, and, during the latter reaction, the higher values of the heat flow were obtained in comparison with pure OPC samples. At later stages of hydration, synthetic CAH affect the OPC hydration as the usual pozzolanic additives; moreover, the larger values of cumulative heat were reached. It should be noted that the nature of synthetic $\mathrm{CAH}$ samples accelerated the dissolution of gypsum and stimulates the earliest $\mathrm{C}_{3} \mathrm{~S}$ hydration.
\end{abstract}

\section{Introduction}

Supplementary cementitious materials (SCMs), including fly ash, ground granulated blast furnace slag, silica fume, calcined clays, and natural pozzolans, are commonly blended with clinker to make Portland cement or are used as a partial replacement of this component in concrete [1-6]. The practice of using SCMs is increasing, with the world average percent clinker in cement having decreased from $85 \%$ in 2003 to $77 \%$ in 2010 , and it is projected to further decrease to $71 \%$ in the future [7]. The use of SCMs is favorable to the industry, generally resulting in concrete with lower cost, lower environmental impact, higher long-term strength, and improved long-term durability [8-10].

It is known that SCMs can be of natural and synthetic origin or used as industrial by-products [11-20]. However, the application of natural minerals or industrial byproducts in cement or concrete production is limited by the energy demanding processing of mentioned materials, which includes crushing, grinding, and size separation and, in some cases, it may also involve thermal activation. The latter process is applied for SCMs, which do not have or reach the required pozzolanic activity and also to alter their physical and chemical properties [11-13, 21].
For this reason, due to the high early strength, thermal and chemical stability, and excellent durability with respect to ordinary Portland cement (OPC) the synthetic SCMs have attracted a great scientific attention, when employed in building and ceramic industries [11,22-29]. The one group of these compounds can be located in the $\mathrm{CaO}-\mathrm{Al}_{2} \mathrm{O}_{3}-\mathrm{SiO}_{2}-$ $\mathrm{H}_{2} \mathrm{O}$ system. During hydrothermal synthesis the interreaction between silica, alumina, and calcium ions results in the formation of compounds such as calcium silicate hydrates $(\mathrm{CSH})$, calcium aluminate hydrates $(\mathrm{CAH})$, and calcium aluminium silicate hydrates (CASH). For this reason, many researchers keep their focus on tailoring the final structural and physical properties of mentioned materials mainly by changing the synthesis conditions (using different raw materials and changing $C / S$ ratio of primary mixture or the duration and temperature of isothermal curing) [30-35]. In Baltakys et al. work, when the duration of hydrothermal synthesis $\left(175^{\circ} \mathrm{C} ; 0-24 \mathrm{~h}\right)$ was extended, a lower amount of CASH was obtained [35]. Meanwhile, in Meller et al. work [31-34] the stability of obtained phases in $\mathrm{CaO}-\mathrm{Al}_{2} \mathrm{O}_{3}-\mathrm{SiO}_{2}-\mathrm{H}_{2} \mathrm{O}$ system was highlighted. It was found that the latter parameter and the formation mechanism of such compounds were significantly influenced by the synthesis temperature (from 200 to $350^{\circ} \mathrm{C}$ ) and even small amounts of $\mathrm{Al}_{2} \mathrm{O}_{3}$ additive. 
TABLE 1: Chemical and mineralogical composition of clinker.

\begin{tabular}{|c|c|c|c|c|c|c|c|c|c|c|}
\hline Oxides & $\mathrm{SiO}_{2}$ & $\mathrm{Al}_{2} \mathrm{O}_{3}$ & $\mathrm{Fe}_{2} \mathrm{O}_{3}$ & $\mathrm{CaO}$ & $\mathrm{MgO}$ & $\mathrm{Na}_{2} \mathrm{O}$ & $\mathrm{K}_{2} \mathrm{O}$ & $\mathrm{SO}_{3}{ }^{2-}$ & Ignition of losses & Insoluble particles \\
\hline Amount, \% & 19.72 & 5.41 & 4.21 & 62.76 & 3.41 & 0.16 & 1.08 & 2.08 & 0.93 & 0.24 \\
\hline Minerals & \multirow{2}{*}{\multicolumn{2}{|c|}{$3 \mathrm{CaO} \cdot \mathrm{SiO}_{2}$}} & \multicolumn{2}{|c|}{$2 \mathrm{CaO} \cdot \mathrm{SiO}_{2}$} & \multicolumn{3}{|c|}{$3 \mathrm{CaO} \cdot \mathrm{Al}_{2} \mathrm{O}_{3}$} & \multicolumn{3}{|c|}{$4 \mathrm{CaO} \cdot \mathrm{Al}_{2} \mathrm{O}_{3} \cdot \mathrm{Fe}_{2} \mathrm{O}_{3}$} \\
\hline Amount, \% & & & \multicolumn{2}{|c|}{8.89} & \multicolumn{3}{|c|}{7.21} & \multicolumn{3}{|c|}{12.81} \\
\hline
\end{tabular}

In previous work [35] the influence of $\mathrm{Al}_{2} \mathrm{O}_{3}$ on the formation of calcium aluminium silicate hydrates under hydrothermal conditions was also examined. It was determined that the largest amount of calcium aluminium silicate hydrates was obtained after $8 \mathrm{~h}$ of hydrothermal treatment at $130^{\circ} \mathrm{C}$, in the mixtures with a higher amount of $\mathrm{Al}_{2} \mathrm{O}_{3}$ $\left(\mathrm{Al}_{2} \mathrm{O}_{3} /\left(\mathrm{SiO}_{2}+\mathrm{Al}_{2} \mathrm{O}_{3}\right)=0.15\right)$. Meanwhile, the formation of mentioned compounds is inhibited, when the duration of isothermal curing is extended from 16 to $72 \mathrm{~h}$.

Aluminium readily enters the calcium silicate hydrate phase $(\mathrm{C}-\mathrm{S}-\mathrm{H})$ of Portland cement, and this substitution is expected to play a significant role in many aspects of the chemical behavior of cement paste, including the cation and anion exchange behavior, solubility, and the progress of the reactions that occur during delayed ettringite formation [3642].

In previous work [35] it was proved that the synthetic $\mathrm{CAH}\left(\mathrm{CaO} /\left(\mathrm{SiO}_{2}+\mathrm{Al}_{2} \mathrm{O}_{3}\right)=0.55 ; \mathrm{Al}_{2} \mathrm{O}_{3} /\left(\mathrm{SiO}_{2}+\mathrm{Al}_{2} \mathrm{O}_{3}\right)=\right.$ $0.15)$ as an additive affects the early hydration of OPC. This compound effectively shortens the induction period and accelerates the second and the third exothermic reactions.

For this reason, the main objective of this study was to determine the effect of synthetic $\mathrm{CAH}$ with different crystallinity on the hydration kinetics of OPC at early stages of hydration. Also, the compound formation mechanism is highlighted.

\section{Materials and Methods}

2.1. Materials. In this paper the following reagents were used: $\mathrm{SiO}_{2} \cdot n \mathrm{H}_{2} \mathrm{O}$ ("Reaktiv," Russia) was grinded for $3 \mathrm{~min}$ in a vibrating cup "Pulverisette 9" mill (speed: $950 \mathrm{rpm}$ ) and sieved through a sieve with a mesh size of $80 \mu \mathrm{m}, S_{a}=$ $1047 \mathrm{~m}^{2} / \mathrm{kg}$ by CILAS LD 1090 granulometer, the loss of ignition, 7.0 wt.\%. Calcium oxide from $\mathrm{Ca}(\mathrm{OH})_{2}$ ("Reaktiv," Russia) was additionally burned at $500^{\circ} \mathrm{C}$ temperature for $2 \mathrm{~h}$, grinded for $30 \mathrm{~s}$ in a vibrating cup "Pulverisette 9" mill (speed: $650 \mathrm{rpm}$ ), and sieved through a sieve with a mesh size of $80 \mu \mathrm{m}$; the quantity of free $\mathrm{CaO}$ is equal to $99 \mathrm{wt} . \%, S_{a}=$ $961 \mathrm{~m}^{2} / \mathrm{kg} \cdot \gamma-\mathrm{Al}_{2} \mathrm{O}_{3}$ was produced by burning aluminium hydroxide ("Sigma-Aldrich," Germany) at $475^{\circ} \mathrm{C}$ for $4 \mathrm{~h}, S_{a}=$ $822 \mathrm{~m}^{2} / \mathrm{kg}$.

2.2. Synthetic CAH Samples Preparation. Dry primary mixtures with $\mathrm{CaO} /\left(\mathrm{SiO}_{2}+\mathrm{Al}_{2} \mathrm{O}_{3}\right)=0.55$ and $\mathrm{Al}_{2} \mathrm{O}_{3} /\left(\mathrm{SiO}_{2}+\right.$ $\left.\mathrm{Al}_{2} \mathrm{O}_{3}\right)=0.1 ; 0.15$ were mixed with water to reach the water/solid ratio of the suspension equal to 10.0. The hydrothermal synthesis has been carried out in unstirred suspensions in $25 \mathrm{~mL}$ volume PTFE cells, which were placed in "Parr instruments" (Germany) autoclave, under saturated steam pressure at $130^{\circ} \mathrm{C}$ temperature for $8 \mathrm{~h}$ (the temperature was reached within $2 \mathrm{~h}$ ). After hydrothermal treatments, the autoclave was quenched to room temperature. The suspensions after synthesis were filtered and products were rinsed with ethanol to prevent carbonization of materials, dried at $50 \pm 5^{\circ} \mathrm{C}$ temperature for $24 \mathrm{~h}$, and sieved through a sieve with a width of $80 \mu \mathrm{m}$. These synthesis conditions were chosen according to previously published data [35].

2.3. Cementitious Admixtures with Synthetic CAH Samples. Samples of OPC were prepared in a laboratory grinding mill by grinding cement clinker (JSC "Akmenes cementas," Lithuania) with a $4.5 \%$ additive of gypsum ("Sigma-Aldrich," Germany) up to $S_{a}=450 \mathrm{~m}^{2} / \mathrm{kg}$. The chemical analysis and phase composition of clinker are shown in Table 1. Synthetic $\mathrm{CAH}$ sample was added as a partial replacement of the OPC at levels of $10 \%$ by weight of the total cementitious material. Therefore the water and cement ratio $(\mathrm{W} / \mathrm{C})$ of all OPC samples was equal to 0.5 .

In the next stage of experiment, synthesized CAH samples were added as a partial replacement of the OPC at levels of $10 \%$ by weight of the total cementitious material. The additives of hydrated calcium aluminate were labeled as OPC-CAH1 $\left(\left(\mathrm{CaO} /\left(\mathrm{SiO}_{2}+\mathrm{Al}_{2} \mathrm{O}_{3}\right)=0.55, \mathrm{Al}_{2} \mathrm{O}_{3} /\left(\mathrm{SiO}_{2}+\right.\right.\right.$ $\left.\left.\left.\mathrm{Al}_{2} \mathrm{O}_{3}\right)=0.1\right)\right)$ and OPC-CAH2 $\left(\mathrm{CaO} /\left(\mathrm{SiO}_{2}+\mathrm{Al}_{2} \mathrm{O}_{3}\right)=0.55\right.$, $\left.\mathrm{Al}_{2} \mathrm{O}_{3} /\left(\mathrm{SiO}_{2}+\mathrm{Al}_{2} \mathrm{O}_{3}\right)=0.15\right)$ depending on the composition of primary mixtures.

2.4. Test Methods. The X-ray powder analysis (XRD) was performed on the D8 Advance diffractometer (Bruker AXS, Karlsruhe, Germany) operating at the tube voltage of $40 \mathrm{kV}$ and tube current of $40 \mathrm{~mA}$. The X-ray beam was filtered with Ni $0.02 \mathrm{~mm}$ filter to select the $\mathrm{CuK}_{\alpha}$ wavelength. Diffraction patterns were recorded in a Bragg-Brentano geometry using a fast counting detector Bruker LynxEye based on silicon strip technology. The specimens were scanned over the range $2 \theta=$ $3-70^{\circ}$ at a scanning speed of $6^{\circ} \mathrm{C} \mathrm{min}^{-1}$ using a coupled twotheta/theta scan type.

Simultaneous thermal analysis (STA: differential scanning calorimetry, DSC, and thermogravimetry, TG) was also employed for measuring the thermal stability and phase transformation of samples at a heating rate of $15^{\circ} \mathrm{C} \mathrm{min}{ }^{-1}$; the temperature ranged from $30^{\circ} \mathrm{C}$ up to $900^{\circ} \mathrm{C}$ under air atmosphere. The test was carried out on a Linseis instrument STA PT1000. The ceramic sample handlers and crucibles of Pt were used.

Differential scanning calorimetry (DSC) analysis was performed by a Netzsch DSC 214 Polyma instrument. This method was employed for measuring the thermal stability and phase transformation of samples at a heating rate of 


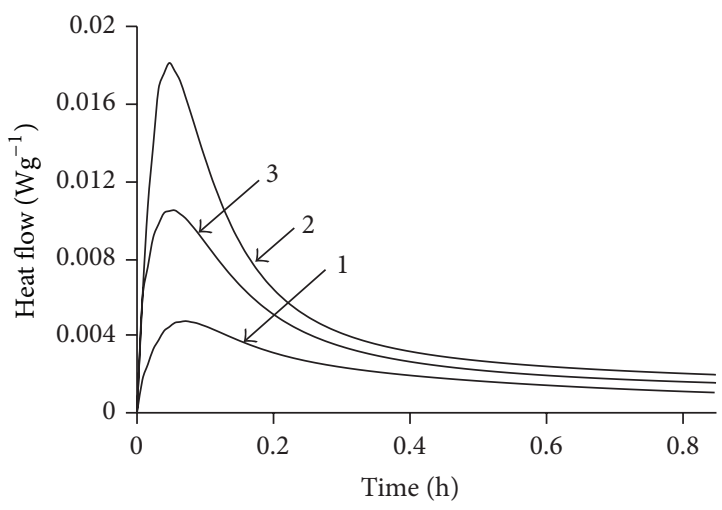

(a)

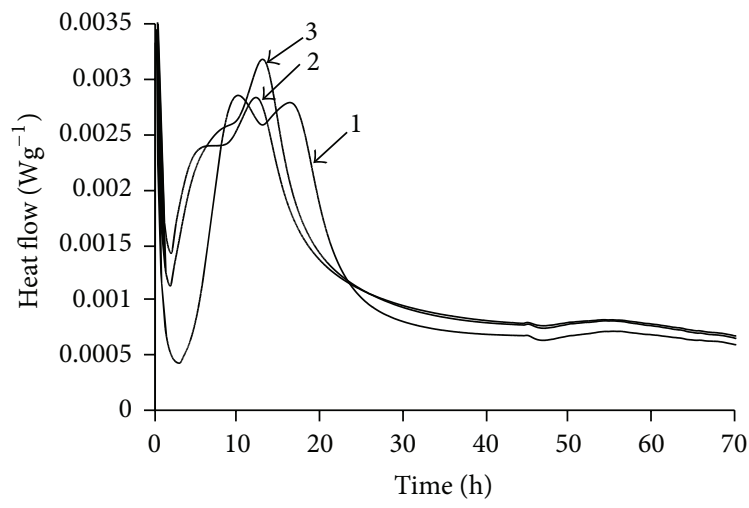

(c)

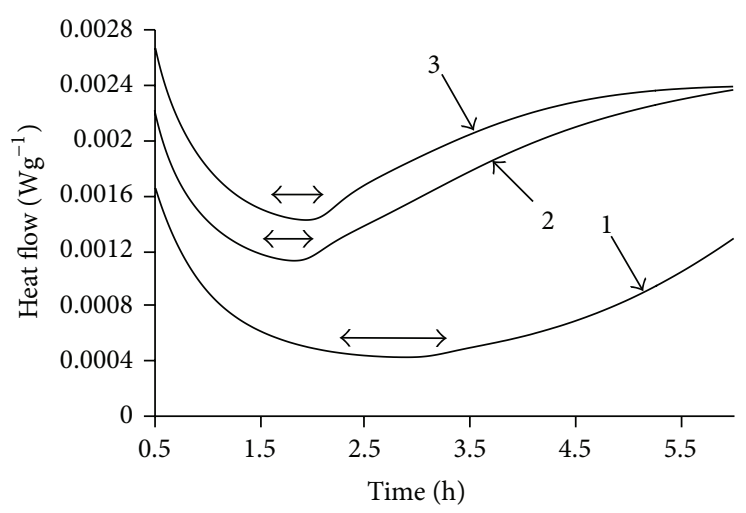

(b)

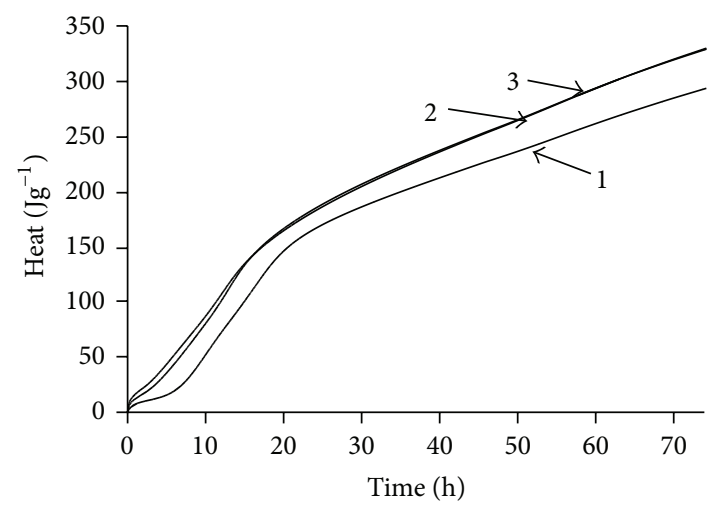

(d)

FIGURE 1: The heat evolution rate (a-c) and cumulative heat (d) of OPC (1), OPC-CAH1 (2), and OPC-CAH2 (3) samples during the early stage of hydration.

$10^{\circ} \mathrm{C} \mathrm{min}^{-1}$, and the temperature ranged from $30^{\circ} \mathrm{C}$ up to $600^{\circ} \mathrm{C}$ under air atmosphere. Ceramic sample handlers and $\mathrm{Al}$ crucibles were used.

An eight-channel TAM Air III isothermal calorimeter was used to investigate the heat evolution rate of the samples. Glass ampoules $(20 \mathrm{~mL}$ ) each containing $3 \mathrm{~g}$ dry cementitious material were placed in the calorimeter and the injection units for each ampoule filled with amounts of water equivalent to a $\mathrm{W} /$ (OPC and additive) ratio of 0.5 . After a steady temperature of $25^{\circ} \mathrm{C}$ had been reached, the water was injected into the ampoules and mixed inside the calorimeter with the dry material for $20 \mathrm{~s}$ (frequency $2-3 \mathrm{~s}^{-1}$ ). The heat evolution rate was then measured over a period of $72 \mathrm{~h}$. Repetition of the measurements showed deviations in total heat below 3\% for samples of similar type. Apart from the first minutes of water additive and mixing, the heat evolution rates were essentially identical. The rate of heat evolution was calculated on the basis of a unit weight of OPC.

In order to investigate the minerology and chemical composition of compounds formed during hydration, the heat evolution experiments were repeated at $25^{\circ} \mathrm{C}$ for different time periods $(1.8,3,9.5,13$, and $24 \mathrm{~h}$ ), which corresponded to the onset/peak/end duration of different early hydration periods. Hydration of samples was stopped by using acetone. Later on, the samples were crushed to powder, dried at the temperature of $50 \pm 5^{\circ} \mathrm{C}$, and put through a sieve with an $80 \mu \mathrm{m}$ mesh.

\section{Results and Discussion}

3.1. Heat Evolution in Hydrated Cementitious Admixtures with Synthetic CAH Samples. The data of cumulative heat of hydration as well as the rate of heat evolution of the binary blended pastes are presented in Figure 1.

The heat of hydration curves for pure OPC and OPC with additives shows the typical five stages of the hydration reaction (the initial reaction, the induction period, the acceleratory period, the deceleratory period, and the period of slow continued reaction) as described in the literature [43-45].

It was determined that the additives of synthetic $\mathrm{CAH}$ samples in OPC samples accelerated the initial reaction (1$2 \mathrm{~min}$ ) because an increase in the maximum heat evolution rate was observed from $0.005 \mathrm{Wg}^{-1}$ to $0.011 \mathrm{Wg}^{-1}$ (OPC$\mathrm{CAH} 2$ ) and $0.018 \mathrm{Wg}^{-1}$ (OPC-CAH1) (Figure 1(a)). And also, the induction period, which is assigned to the growing $\mathrm{C}$ $\mathrm{S}-\mathrm{H}$ and $\mathrm{CH}$ on the surface of the particles of primary compounds, was effectively shortened. In pure OPC samples, the mentioned process continued after $3 \mathrm{~h}$, while in a case of OPC-CAH1 and OPC-CAH1 only after $\sim 1.8 \mathrm{~h}$ (Figure $1(\mathrm{~b})$ ). However, the accelerating effect begun earlier: from $1.9 \mathrm{~h}$ 


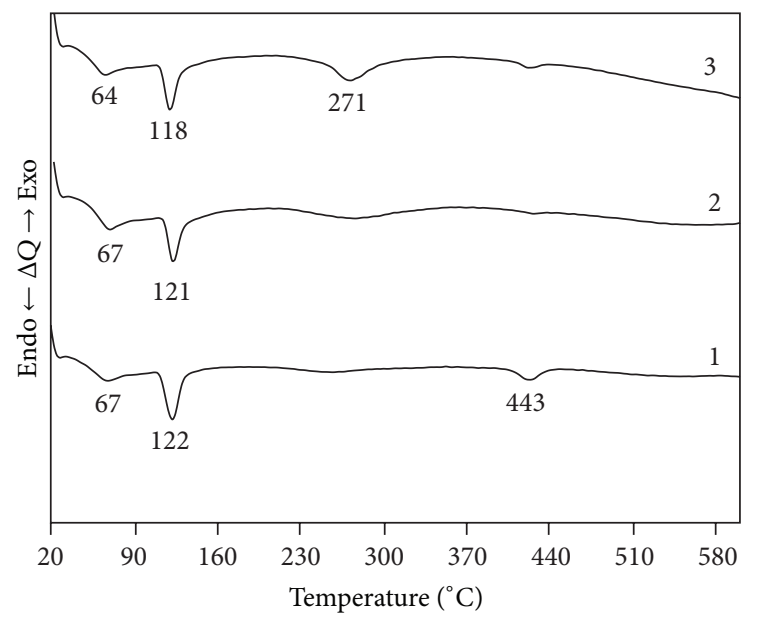

(a)

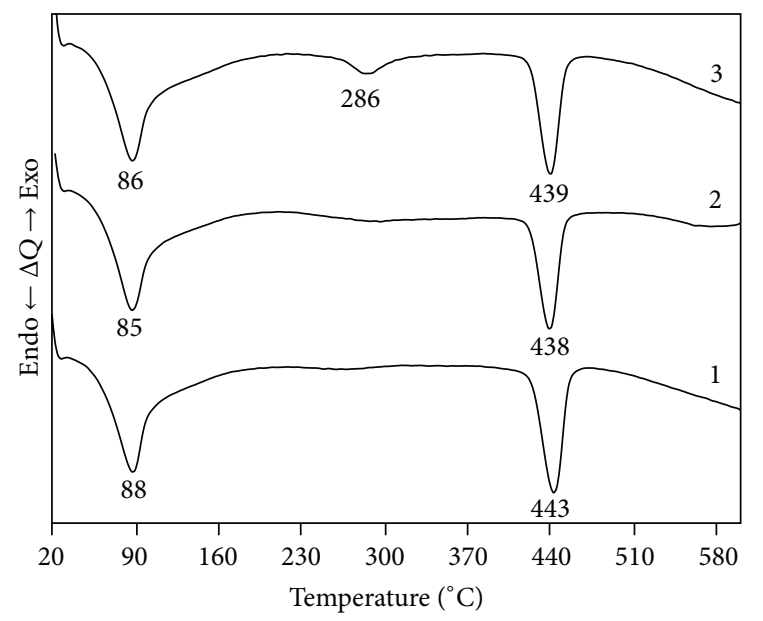

(b)

FIGURE 2: DSC curves OPC with 10 wt.\% additive after $1.8 \mathrm{~h}$ (a) and $16.5 \mathrm{~h}$ (b): 1, OPC; 2, OPC-CAH1; 3, OPC-CAH2.

in the samples with an additive and from $3.2 \mathrm{~h}$ in pure OPC samples (Figure 1(c)). Moreover, the lower values of the heat flow of the second exothermic reaction, typical to the dissolution of $\mathrm{C}_{3} \mathrm{~S}$, were reached in $\mathrm{OPC}$ mixtures with additives: $0.0023 \mathrm{Wg}^{-1}$ at $5.02 \mathrm{~h}$ for OPC-CAH1 and $0.0023 \mathrm{Wg}^{-1}$ at $6.02 \mathrm{~h}$ for OPC-CAH2. Meanwhile, during the third exothermic reaction, which is characteristic to the dissolution of $\mathrm{C}_{3} \mathrm{~A}$ and the formation of ettringite, the highest value of the heat flow $\left(0.0032 \mathrm{Wg}^{-1}\right)$ at $13.1 \mathrm{~h}$ was obtained in OPC-CAH2 sample (Figure 1(c)).

At later stages of hydration, synthetic $\mathrm{CAH}$ samples affect the OPC hydration as the usual pozzolanic additive; moreover, the largest value of cumulative heat was reached in the OPC-CAH2 sample (Figure 1(d)).

3.2. Quantity of Compounds in the Cement Paste. It was determined that, during early OPC hydration, the stability and reactivity of OPC-CAH1 and OPC-CAH2 significantly depend on the primary mixture composition used for hydrothermal synthesis. OPC-CAH1 additive fully reacted already after $1.8 \mathrm{~h}$ of hydration; meanwhile, in a case of OPC$\mathrm{CAH} 2$, only $33 \%(14.65 \mathrm{~J} / \mathrm{g})$ of calcium aluminium hydrate reacted (Figure 2(a): endothermic effect at $\sim 271^{\circ} \mathrm{C}$; Table 2).

However, when the duration of OPC hydration was extended to $24 \mathrm{~h}$, the amount of unreactive compounds was decreased (Figure 2; Table 2).

It should be noted that the nature of $\mathrm{CAH}$ accelerated the dissolution of gypsum. In the pure system, the latter compound fully reacted only after 16.5 hours of hydration, whereas in the samples with additives it fully reacted already after $13 \mathrm{~h}$. It is clearly visible in DSC curve: the endothermic effect in a $105-135^{\circ} \mathrm{C}$ temperature range, which corresponded to the dehydration of gypsum, disappeared (Figure 2; Table 3). Moreover, in comparison with pure OPC samples, only a smaller amount of semicrystalline C-S-H (Figure 2: endothermic effect at $67^{\circ} \mathrm{C}$; Table 3) as well as portlandite (Figure 2: endothermic effect at $440^{\circ} \mathrm{C}$; Table 3)

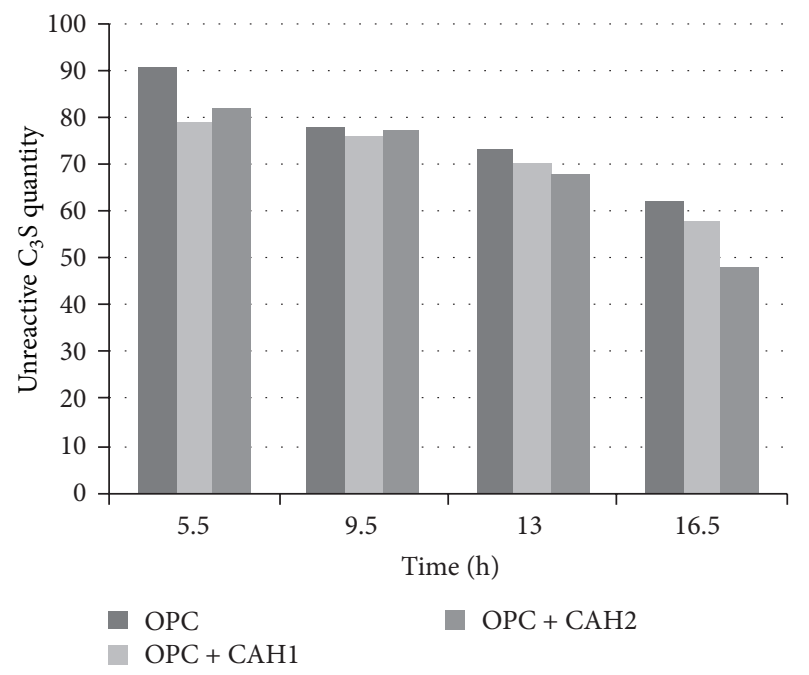

FIGURE 3: The quantity of unreactive $\mathrm{C}_{3} \mathrm{~S}$ in pure OPC, OPC-CAH1, and OPC-CAH2 samples after different duration of hydration.

were obtained in the mixtures with additives by prolonging the duration of OPC hydration.

In this report, the amounts of $\mathrm{C}_{3} \mathrm{~S}$ that have reacted after heat evolution experiments at different time period under normal conditions were determined by the quantitative analysis (QXRD). The quantity of $\mathrm{C}_{3} \mathrm{~S}$ was calculated from the intensity change of the basic reflection ( $d$-spacing, $0.2604 \mathrm{~nm}$ ). Each calculation was done five times, and it was determined that their data declined no more than $\pm 2 \%$ from the mean (Figure 3). $\mathrm{C}_{3} \mathrm{~S}$ quantity in the mixtures of pure $\mathrm{OPC}$ and OPC with additives (before hydration) was equal to $100 \%$.

It was determined that after $5.5 \mathrm{~h}$ of hydration, only $9 \%$ of $\mathrm{C}_{3} \mathrm{~S}$ reacts in pure OPC samples and the further reduction of its quantity depends on duration of hydration (Figure 3). 
TABLE 2: The main characteristics of thermal effects typical of CAH.

\begin{tabular}{cccccc}
\hline Composition & Hydration time $(\mathrm{h})$ & Onset, ${ }^{\circ} \mathrm{C}$ & Peak, ${ }^{\circ} \mathrm{C}$ & Heat of process, J/g & Unreacted CAH, wt.\% \\
\hline 0 & 250.2 & 268.6 & 21.81 & 100 \\
& 1.8 & 253.8 & 271.0 & 14.65 & 67.17 \\
OPC-CAH2 & 254.5 & 273.3 & 14.51 & 66.53 \\
& 5.5 & 256.7 & 276.3 & 13.67 & 62.68 \\
& 9.5 & 261.6 & 280.5 & 12.24 & 56.12 \\
& 13 & 265.2 & 282.5 & 11.94 & 54.75 \\
& 16.5 & 264.1 & 286.0 & 11.71 & 53.69 \\
\\
24 & 267.7 & 286.8 & 10.39 & 47.64 \\
\hline
\end{tabular}

TABLE 3: The main characteristics of thermal effects typical of CSH and gypsum by DSC method.

\begin{tabular}{|c|c|c|c|c|c|c|c|c|}
\hline \multirow{2}{*}{ Composition } & \multirow{2}{*}{$\begin{array}{c}\text { Hydration } \\
\text { time (h) }\end{array}$} & \multicolumn{3}{|c|}{$\mathrm{CSH}$} & \multicolumn{4}{|c|}{ Gypsum } \\
\hline & & Onset, ${ }^{\circ} \mathrm{C}$ & Peak, ${ }^{\circ} \mathrm{C}$ & Heat of process, J/g & Onset, ${ }^{\circ} \mathrm{C}$ & Peak, ${ }^{\circ} \mathrm{C}$ & Heat of process, J/g & Unreacted gypsum, wt.\% \\
\hline \multirow{7}{*}{ OPC } & 1.8 & 45.8 & 66.7 & 14.89 & 112.5 & 122.4 & 16.23 & 69.01 \\
\hline & 3 & 48.0 & 64.4 & 17.22 & 108.1 & 118.3 & 16.69 & 70.96 \\
\hline & 5.5 & 52.4 & 73.6 & 28.12 & 111.1 & 119.4 & 10.97 & 46.64 \\
\hline & 9.5 & 54.7 & 76.9 & 40.88 & 113.3 & 119.8 & 6.86 & 29.15 \\
\hline & 13 & 57.5 & 82.0 & 53.01 & 116.2 & 121.3 & 0.80 & 3.36 \\
\hline & 16.5 & 61.0 & 87.8 & 71.84 & - & - & - & - \\
\hline & 24 & 58.8 & 86.3 & 77.42 & - & - & - & - \\
\hline \multirow{7}{*}{ OPC-CAH1 } & 1.8 & 49.0 & 66.8 & 18.61 & 113.6 & 121.0 & 13.63 & 74.93 \\
\hline & 3 & 48.4 & 68.0 & 22.53 & 112.2 & 119.4 & 10.33 & 43.92 \\
\hline & 5.5 & 54.5 & 75.7 & 37.60 & 115.1 & 121.0 & 6.02 & 25.57 \\
\hline & 9.5 & 58.7 & 81.5 & 51.10 & 116.6 & 122.7 & 0.29 & 1.24 \\
\hline & 13 & 62.7 & 87.6 & 63.13 & - & - & - & - \\
\hline & 16.5 & 59.5 & 84.8 & 66.49 & - & - & - & - \\
\hline & 24 & 58.5 & 84.5 & 71.74 & - & - & - & - \\
\hline \multirow{7}{*}{ OPC-CAH2 } & 1.8 & 44.4 & 63.0 & 17.20 & 110.5 & 118.3 & 13.54 & 67.60 \\
\hline & 3 & 49.4 & 69.3 & 21.10 & 111.7 & 119.6 & 11.15 & 55.67 \\
\hline & 5.5 & 55.2 & 76.9 & 37.32 & 114.7 & 120.8 & 4.74 & 23.68 \\
\hline & 9.5 & 64.7 & 85.1 & 54.86 & 116 & 121.8 & 0.51 & 2.54 \\
\hline & 13 & 61.9 & 85.8 & 64.14 & - & - & - & - \\
\hline & 16.5 & 61.4 & 85.1 & 58.51 & - & - & - & - \\
\hline & 24 & 60.2 & 86.6 & 66.50 & - & - & - & - \\
\hline
\end{tabular}

Meanwhile, within the same duration of hydration, in the samples with CAH1 and CAH 2 additives, $21 \%$ and $18 \%$ of this compound reacted, respectively (Figure 3 ). It was noticed that mentioned additives stimulate the earliest $\mathrm{C}_{3} \mathrm{~S}$ hydration in all samples (5.5-16.5 h) (Figure 3).

Presumably, the synthetic CAH sample also induced the formation mechanism of ettringite.

In order to prove this fact, the intensity change of the basic reflection of ettringite $(d$-spacing, $0.972 \mathrm{~nm})$ in cement samples was evaluated by X-ray diffraction analysis (XRD) according to the area of mentioned diffraction maximum per shift at different hydration time.

The obtained results showed that after 3 hours of hydration, the area of the main diffraction peak typical to ettringite increased in two times in comparison with the pure OPC samples (Figure 4). The same tendency was also observed,
TABLE 4: The values of the main diffraction peak area of ettringite in OPC, OPC-CAH1, and OPC-CAH2 samples.

\begin{tabular}{lcccccccc}
\hline \multirow{2}{*}{ Composition } & \multicolumn{8}{c}{ Hydration time (h) } \\
& 0 & 1.8 & 3 & 5.5 & 9.5 & 13 & 16.5 & 24 \\
\hline OPC & - & 0.14 & 0.15 & 0.26 & 0.40 & 0.60 & 1.00 & 1.45 \\
OPC-CAH1 & - & 0.15 & 0.37 & 0.42 & 0.89 & 0.90 & 1.18 & 1.39 \\
OPC-CAH2 & - & 0.21 & 0.22 & 0.54 & 0.51 & 1.03 & 1.18 & 1.30 \\
\hline
\end{tabular}

when the duration of hydration was extended to 9.5 hours (Table 4).

In addition, due to the accelerated dissolution of gypsum, a larger amount of formed ettringite was observed in OPC$\mathrm{CAH} 1$ and OPC-CAH2 samples. Meanwhile, in an excess 


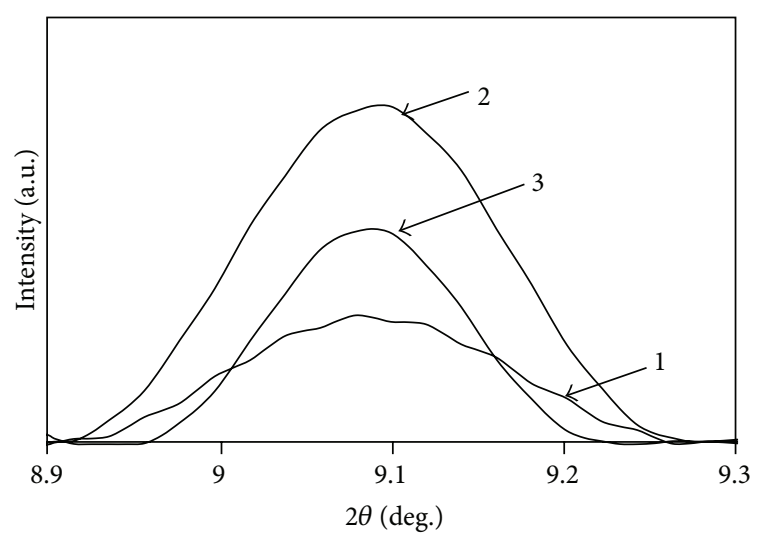

FIGURE 4: The change of the main diffraction peak of ettringite in samples after $3 \mathrm{~h}$ of hydration: 1, OPC; 2 , OPC-CAH1; 3, OPC$\mathrm{CAH} 2$.

of gypsum in the pure OPC samples, the area of the main diffraction maximum of ettringite was slightly higher after $24 \mathrm{~h}$ of hydration (Table 4 ).

\section{Conclusions}

It was examined that the additives accelerated the initial reaction and shortened the induction period. Also, the second and third exothermic reactions begun earlier, and, during the latter reaction, the higher values of the heat flow were obtained in comparison with pure OPC samples. At later stages of hydration, synthetic $\mathrm{CAH}$ affect the OPC hydration as the usual pozzolanic additives; moreover, the larger values of cumulative heat were reached.

It was noticed that additives stimulate the earliest $\mathrm{C}_{3} \mathrm{~S}$ hydration (5.5-16.5 h): after $5.5 \mathrm{~h}$ of hydration, only $9 \%$ of $\mathrm{C}_{3} \mathrm{~S}$ reacts in pure OPC samples and the further reduction of its quantity depends on duration of hydration. Meanwhile, in a case of $\mathrm{CAH} 1$ and $\mathrm{CAH} 2$ additives, $21 \%$ and $18 \%$ of this compound reacted.

It should be noted that the nature of synthetic CAH samples accelerated the dissolution of gypsum. In the pure system, the latter compound fully reacted only after 16.5 hours of hydration, whereas in the samples with additives it reacted already after $13 \mathrm{~h}$. For this reason, a larger amount of formed ettringite was observed in OPC-CAH1 and OPC$\mathrm{CAH} 2$ samples till $16.5 \mathrm{~h}$ of hydration.

\section{Competing Interests}

The authors declare that there is no conflict of interests regarding the publication of this paper.

\section{Acknowledgments}

This research was funded by a grant (no. MIP-025/2014) from the Research Council of Lithuania.

\section{References}

[1] C. H. Un, J. G. Sanjayan, R. San Nicolas, and J. S. J. van Deventer, "Predictions of long-term deflection of geopolymer concrete beams," Construction and Building Materials, vol. 94, pp. 10-19, 2015.

[2] E. Gartner and H. Hirao, "A review of alternative approaches to the reduction of $\mathrm{CO}_{2}$ emissions associated with the manufacture of the binder phase in concrete," Cement and Concrete Research, vol. 78, pp. 126-142, 2015.

[3] K.-H. Yang, Y.-B. Jung, M.-S. Cho, and S.-H. Tae, "Effect of supplementary cementitious materials on reduction of $\mathrm{CO}_{2}$ emissions from concrete," Journal of Cleaner Production, vol. 103, pp. 774-783, 2015.

[4] E. Aprianti, P. Shafigh, S. Bahri, and J. N. Farahani, "Supplementary cementitious materials origin from agricultural wastes-a review," Construction and Building Materials, vol. 74, pp. 176187, 2015.

[5] S. H. Kosmatka, B. Kerkhoff, and W. C. Panarese, "Fly ash, slag, silica fume, and natural pozzolans," in Design and Control of Concrete Mixtures, EB001, chapter 3, Portland Cement Association, 14th edition, 2008.

[6] M. H. Cornejo, J. Elsen, C. Paredes, and H. Baykara, “Thermomechanical treatment of two Ecuadorian zeolite-rich tuffs and their potential usage as supplementary cementitious materials," Journal of Thermal Analysis and Calorimetry, vol. 115, no. 1, pp. 309-321, 2014.

[7] M. C. G. Juenger and R. Siddique, "Recent advances in understanding the role of supplementary cementitious materials in concrete," Cement and Concrete Research, vol. 78, pp. 71-80, 2015.

[8] A. Korpa, T. Kowald, and R. Trettin, "Hydration behaviour, structure and morphology of hydration phases in advanced cement-based systems containing micro and nanoscale pozzolanic additives," Cement and Concrete Research, vol. 38, no. 7, pp. 955-962, 2008.

[9] N. M. Khalil, E. M. Hassan, M. M. E. Shakdofa, and M. Farahat, "Beneficiation of the huge waste quantities of barley and rice husks as well as coal fly ashes as additives for Portland cement," Journal of Industrial and Engineering Chemistry, vol. 20, no. 5, pp. 2998-3008, 2014.

[10] M. Hamidi, L. Kacimi, M. Cyr, and P. Clastres, "Evaluation and improvement of pozzolanic activity of andesite for its use in ecoefficient cement," Construction and Building Materials, vol. 47, pp. 1268-1277, 2013.

[11] M. S. Amin, S. A. Abo-El-Enein, A. A. Rahman, and K. A. Alfalous, "Artificial pozzolanic cement pastes containing burnt clay with and without silica fume: physicochemical, microstructural and thermal characteristics," Journal of Thermal Analysis and Calorimetry, vol. 107, no. 3, pp. 1105-1115, 2012.

[12] B. Lothenbach, K. Scrivener, and R. D. Hooton, "Supplementary cementitious materials," Cement and Concrete Research, vol. 41, no. 12, pp. 1244-1256, 2011.

[13] C. A. Utton, M. Hayes, J. Hill, N. B. Milestone, and J. H. Sharp, "Effect of temperatures up to $90^{\circ} \mathrm{C}$ on the early hydration of Portland-Blastfurnace slag cements," Journal of the American Ceramic Society, vol. 91, pp. 948-954, 2008.

[14] L. Krishnan, S. Karthikeyan, S. Nathiya, and K. Suganya, "Geopolymer concrete an eco-friendly construction material," International Journal of Research in Engineering and Technology, vol. 3, pp. 164-167, 2014. 
[15] M. E. Natali, S. Manzi, C. Chiavari, and M. C. Bignozzi, "Steel reinforced geopolymer mortar: corrosion behaviour in chloride-rich environment," in Proceedings of the 34th Cement and Concrete Science Conference, S. A. Bernal and J. L. Provis, Eds., pp. 41-44, University of Sheffield, September 2014.

[16] A. Rafeet, R. Vinai, W. Sha, and M. Soutsos, "Alkali activated fuel ash and slag mixes: optimization study from mortars to concrete building blocks," in Proceedings of the 34th Cement and Concrete Science Conference, S. A. Bernal and J. L. Provis, Eds., pp. 349354, University of Sheffield, September 2014.

[17] C. Villa, E. T. Pecina, R. Torres, and L. Gómez, "Geopolymer synthesis using alkaline activation of natural zeolite," Construction and Building Materials, vol. 24, no. 11, pp. 2084-2090, 2010.

[18] M. Babaee, A. Castel, and A. Akbarnezhad, "Active steel corrosion in blended slag and fly ash geopolymer concrete," in Proceedings of 34th Cement and Concrete Science Conference, S. A. Bernal and J. L. Provis, Eds., pp. 55-58, University of Sheffield, Sheffield, UK, 2014.

[19] T. Bakharev, "Geopolymeric materials prepared using Class F fly ash and elevated temperature curing," Cement and Concrete Research, vol. 35, no. 6, pp. 1224-1232, 2005.

[20] T. Bakharev, "Resistance of geopolymer materials to acid attack," Cement and Concrete Research, vol. 35, no. 4, pp. 658-670, 2005.

[21] P. K. Mehta and P. J. M. Monteiro, Concrete: Microstructure, Properties, and Materials, The McGraw-Hill Companies, 3rd edition, 2005.

[22] G. Roviello, L. Ricciotti, C. Ferone, F. Colangelo, and R. Cioffi, "Hybrid organic-inorganic materials: novel perspectives for the application of geopolymer based materials," in Proceedings of the 34th Cement and Concrete Science Conference, S. A. Bernal and J. L. Provis, Eds., pp. 199-202, University of Sheffield, 2014.

[23] K. Baltakys, A. Eisinas, T. Dizhbite, L. Jasina, R. Siauciunas, and S. Kitrys, "The influence of hydrothermal synthesis conditions on gyrolite texture and specific surface area," Materials and Structures, vol. 44, no. 9, pp. 1687-1701, 2011.

[24] K. Baltakys, R. Siauciunas, R. Gendvilas, A. Eisinas, T. Dambrauskas, and S. Kitrys, "Physically and chemically bound $\mathrm{H}_{2} \mathrm{O}$ in the $\alpha-\mathrm{C}_{2} \mathrm{~S}$ hydrate structure," Journal of Thermal Analysis and Calorimetry, vol. 118, no. 2, pp. 807-816, 2014.

[25] H. C. Yong, H. Kamarudin, M. M. Al Bakri Abdullah, and L. Y. Ming, "Effect of alkali concentration on mechanical properties of kaolin geopolymers," Romanian Journal of Materials, vol. 42, no. 2, pp. 179-186, 2012.

[26] M. A. Longhi, F. Gaedke, E. D. Rodríguez, A. C. Passuello, and A. P. Kirchheim, "Geopolymers based on calcined kaolin sludge/bottom ash blends and an alternative sodium silicate activator," in Proceedings of 34th Cement and Concrete Science Conference, S. A. Bernal and J. L. Provis, Eds., pp. 359-362, University of Sheffield, 2014.

[27] B. Walkley and J. S. J. van Deventer, "Stoichiometrically controlled C-A-S-H / N-A-S-H gel blends via alkali-activation of synthetic precursors," in Proceedings of the 34th Cement and Concrete Science Conference, S. A. Bernal and J. L. Provis, Eds., pp. 27-32, University of Sheffield, Sheffield, UK, 2014.

[28] K. Baltakys, T. Dambrauskas, R. Siauciunas, and A. Eisinas, "The formation of $\alpha-\mathrm{C}_{2} \mathrm{~S}$ hydrate in the mixtures with $\mathrm{CaO} / \mathrm{SiO}_{2}=1.75$ by hydrothermal treatment at $200^{\circ} \mathrm{C}$," Revista Romana de Materiale_Romanian Journal of Materials, vol. 44, pp. 109-155, 2014.

[29] G. Mucsi, Z. Molnár, Á. Rácz, R. Szabó, and B. Csőke, “Geopolymer from mechanically activated low and high calcium fly ash," in Proceedings of the 34th Cement and Concrete Science Conference, S. A. Bernal and J. L. Provis, Eds., pp. 1391-1396, University of Sheffield, Sheffield, UK, 2014.

[30] R. Siauciunas and A. Baltusnikas, "Influence of $\mathrm{SiO}_{2}$ modification on hydrogarnets formation during hydrothermal synthesis," Cement and Concrete Research, vol. 33, no. 11, pp. 1789-1793, 2003.

[31] N. Meller, C. Hall, K. Kyritsis, and G. Giriat, "Synthesis of cement based $\mathrm{CaO}-\mathrm{Al}_{2} \mathrm{O}_{3}-\mathrm{SiO}_{2}-\mathrm{H}_{2} \mathrm{O}$ (CASH) hydroceramics at 200 and $250{ }^{\circ} \mathrm{C}$ : ex-situ and in-situ diffraction," Cement and Concrete Research, vol. 37, no. 6, pp. 823-833, 2007.

[32] N. Meller, K. Kyritsis, and C. Hall, "The mineralogy of the CaO$\mathrm{Al}_{2} \mathrm{O}_{3}-\mathrm{SiO}_{2}-\mathrm{H}_{2} \mathrm{O}$ (CASH) hydroceramic system from 200 to 350 ○C," Cement and Concrete Research, vol. 39, no. 1, pp. 45$53,2009$.

[33] N. Meller, C. Hall, and J. S. Phipps, "A new phase diagram for the $\mathrm{CaO}-\mathrm{Al}_{2} \mathrm{O}_{3}-\mathrm{SiO}_{2}-\mathrm{H}_{2} \mathrm{O}$ hydroceramic system at $200{ }^{\circ} \mathrm{C}$," Materials Research Bulletin, vol. 40, no. 5, pp. 715-723, 2005.

[34] N. Meller, K. Kyritsis, and C. Hall, "The hydrothermal decomposition of calcium monosulfoaluminate 14-hydrate to katoite hydrogarnet and $\beta$-anhydrite: an in-situ synchrotron $\mathrm{X}$-ray diffraction study," Journal of Solid State Chemistry, vol. 182, no. 10, pp. 2743-2747, 2009.

[35] K. Baltakys, A. Eisinas, J. Doneliene, D. Monstvilaite, A. Bankauskaite, and A. Urbutis, "The hydrothermal synthesis of calcium aluminium silicate hydrates and its application on Portland cement hydration," Romanian Journal of Materials, vol. 45, no. 3, pp. 218-225, 2015.

[36] C. A. Ríos, C. D. Williams, and M. A. Fullen, "Hydrothermal synthesis of hydrogarnet and tobermorite at $175 \circ \mathrm{C}$ from kaolinite and metakaolinite in the $\mathrm{CaO}-\mathrm{Al}_{2} \mathrm{O}_{3}-\mathrm{SiO}_{2}-\mathrm{H}_{2} \mathrm{O}$ system: a comparative study," Applied Clay Science, vol. 43, no. 2, pp. 228237, 2009.

[37] I. G. Richardson, "The nature of C-S-H in hardened cements," Cement and Concrete Research, vol. 29, no. 8, pp. 1131-1147, 1999.

[38] I. G. Richardson and J. G. Cabrera, "Nature of C-S-H in model slag-cements," Cement and Concrete Composites, vol. 22, no. 4, pp. 259-266, 2000.

[39] A. R. Brough, A. Katz, G.-K. Sun, L. J. Struble, R. J. Kirkpatrick, and J. F. Young, "Adiabatically cured alkali-activated cementbased wasteforms containing high levels of fly ash, formation of zeolites and Al-substituted C-S-H," Cement and Concrete Research, vol. 31, pp. 1437-1447, 2001.

[40] J. Schneider, M. A. Cincotto, and H. Panepucci, "29Si and 27Al high-resolution NMR characterization of calcium silicate hydrate phases in activated blast-furnace slag pastes," Cement and Concrete Research, vol. 31, no. 7, pp. 993-1001, 2001.

[41] O. P. Shrivastava and R. Shrivastava, " $\mathrm{Sr}^{2+}$ uptake and leachability study on cured aluminum-substituted tobermorite-OPC admixtures," Cement and Concrete Research, vol. 31, no. 9, pp. 1251-1255, 2001.

[42] S.-Y. Hong and F. P. Glasser, "Alkali sorption by C-S-H and C-A-S-H gels: part II. Role of alumina," Cement and Concrete Research, vol. 32, no. 7, pp. 1101-1111, 2002.

[43] D. Jansen, F. Goetz-Neunhoeffer, B. Lothenbach, and J. Neubauer, "The early hydration of Ordinary Portland Cement (OPC): an approach comparing measured heat flow with calculated heat flow from QXRD," Cement and Concrete Research, vol. 42, no. 1, pp. 134-138, 2012. 
[44] P. Juilland, E. Gallucci, R. Flatt, and K. L. Scrivener, "Dissolution theory applied to the induction period in alite hydration," Cement and Concrete Research, vol. 40, no. 6, pp. 831-844, 2010.

[45] A. Kumar, S. Bishnoi, and K. L. Scrivener, "Modelling early age hydration kinetics of alite," Cement and Concrete Research, vol. 42, no. 7, pp. 903-918, 2012. 

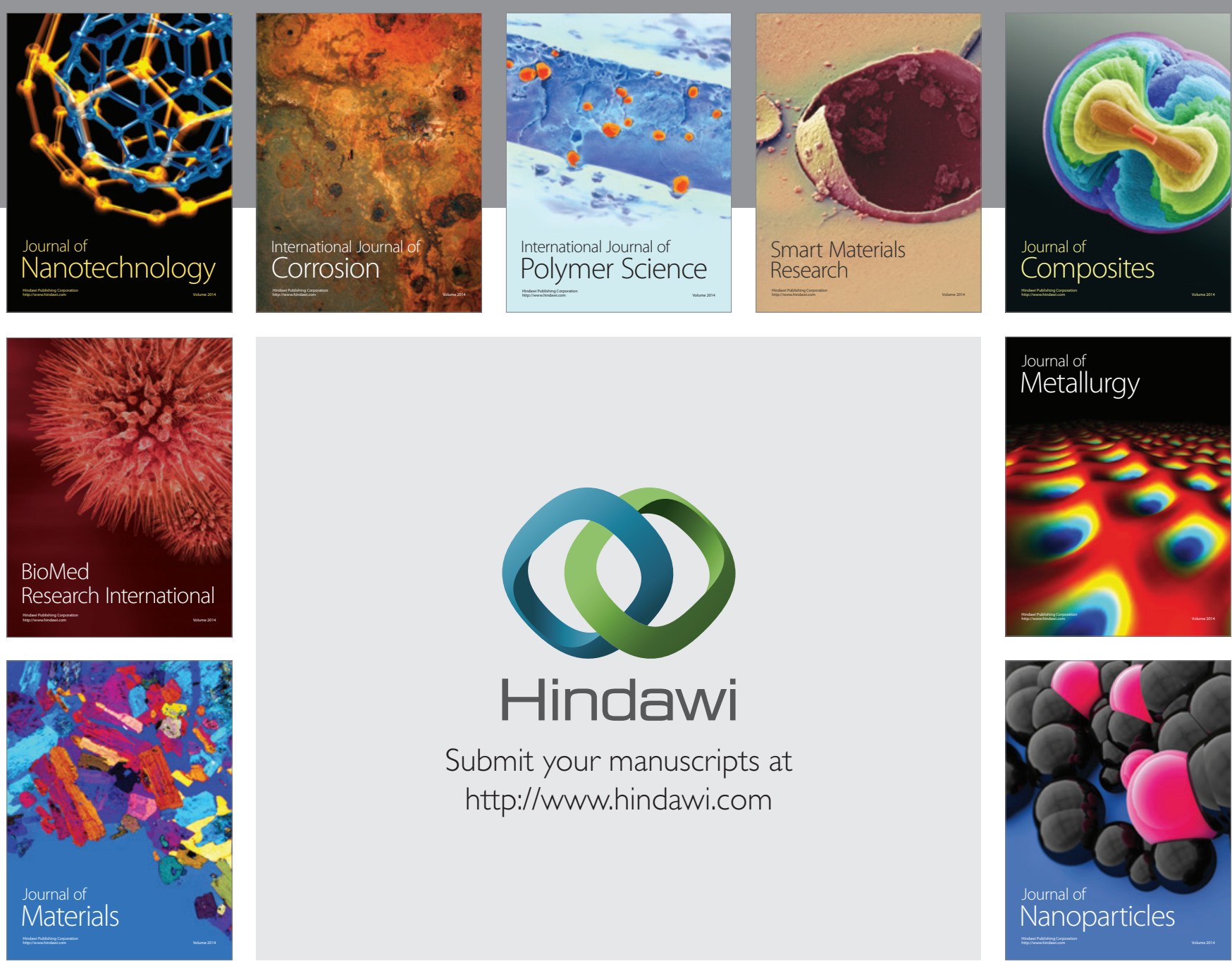

\section{Hindawi}

Submit your manuscripts at

http://www.hindawi.com

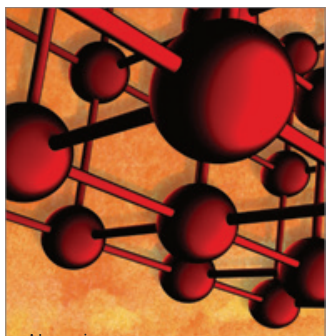

Materials Science and Engineering
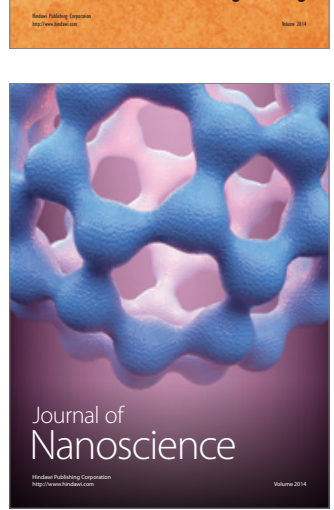
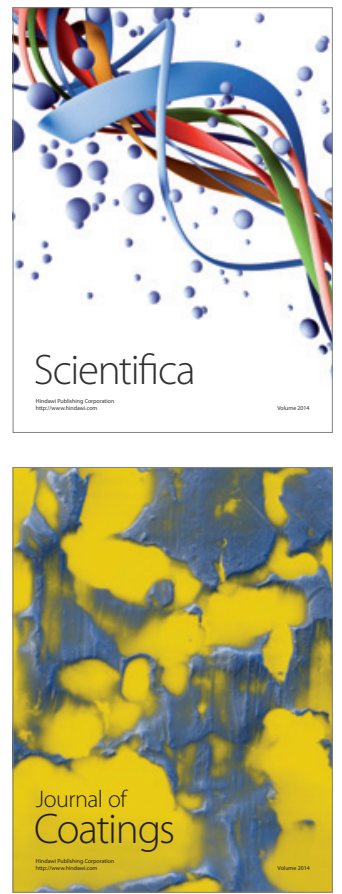
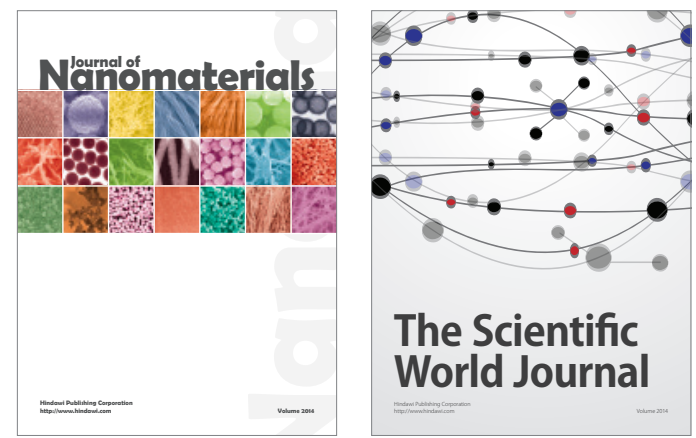

The Scientific World Journal
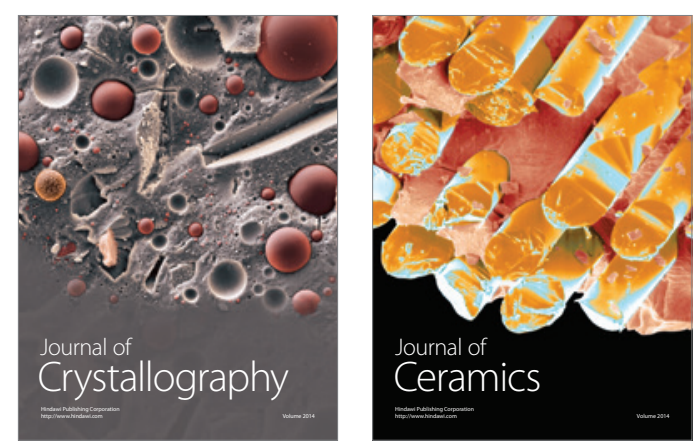
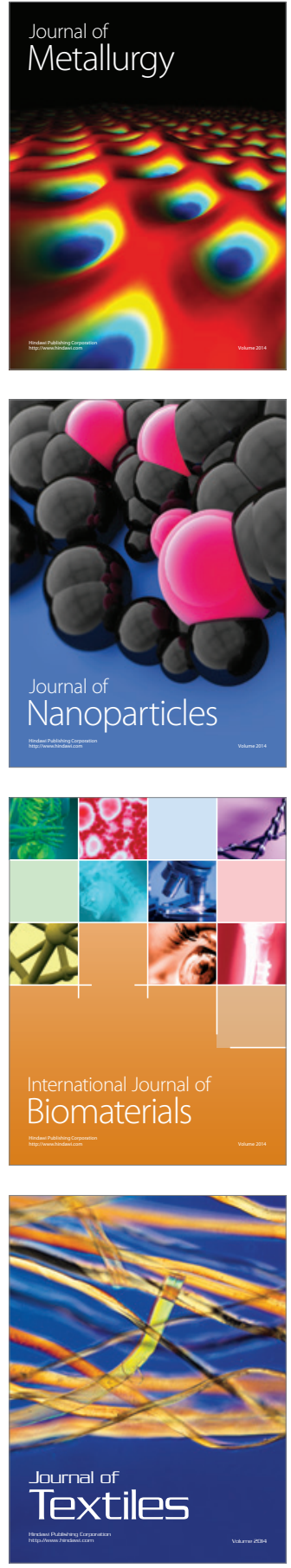